\title{
RESEARCH PROJECTS ON THE ILIMAUSSAQ ALKALINE INTRUSION, SOUTH GREENLAND
}

\author{
Steen Andersen, John Bailey, Sven Karup-Mфller, Laust Løkkegaard, \\ John Rose-Hansen, Agnete Steenfelt and Henning Sørensen
}

The season's field work on the Ilímaussaq intrusion was overshadowed by the disappearance of one of the investigation team, Laust Løkkegaard, who following a day in the field, failed to return to base-camp Dyrnæs. In a subsequent search members of the team, helped by volunteers from Narssaq and by helicopter and fixed-wing aircraft, failed to locate L $\varnothing$ kkegaard. This tragic event occurred in the beginning of August.

The 1972 field work was concerned with the following research projects.

Geochemistry of the main rock types and their minerals (John Bailey \& John Rose-Hansen).

Fifteen large $(50 \mathrm{~kg})$ and a hundred smaller $(17 \mathrm{~kg})$ rock samples were collected by blasting. The material will be used for study of:

(a) the detailed geochemistry of the rocks and minerals of the intrusion by means of x-ray fluorescence, optical spectrography, isotope fluorescence, $\gamma$ ray spectrometry, delayed neutron analysis, fluorimetry, fission track analysis and neutron activation analysis;

(b) gas-liquid inclusions in the minerals. This study is made in cooperation with E. Larsen, at the Atomic Energy Commission's Research Establishment at Ris $\varnothing$;

(c) the reaction of sandstone inclusions in the augite syenite to form alkali granite;

(d) the interaction of lujavrite with naujaite.

Geochemistry of water in the rivers and lakes (John Rose-Hansen)

In cooperation with Gert Asmund at the Atomic Energy Commission's Research Establishment at Ris $\varnothing$, ion exchange samplers were placed in rivers and lakes in order to be able to determine the contents of heavy metals. In addition water was sampled for fluorine and uranium determination.

Field mapping of heterogeneous foyaite, pulaskite, quartz syenite and alkali granite (Agnete Steenfelt)

Mapping was concentrated in two areas; namely in the foyaite-pulaskite area south of Tunugdliarfik fjord and in the area between the Taseq lake and Tunugdliarfik fjord. The study indicates that the acid rocks and parts of the pulaskite of these areas occur as xenoliths in the foyaite. In the Nunasarnaussaq region 
a contact between augite syenite and pulaskite was observed for the first time. The contact is sharp, but no signs of chilling exist on either side. The thicknesses of the horizons of heterogeneous foyaite and sodalite foyaite vary within wide limits and the two rock types may even be lacking locally. Small masses of naujaite have been observed in the sodalite foyaite.

Samples of all rock types were collected, some of which have been handed over to Lotte Melchior Larsen for a study on the compositional variations of the pyroxenes.

\section{The geochemistry of eudialyte (Agnete Steenfelt)}

Two hundred samples containing eudialyte were collected from rock types across the intrusion. During the last two years Henning Bohse and Agnete Steenfelt have examined a number of samples of eudialyte by means of the fission track method. These samples obtained in sections through sodalite foyaite, naujaite and kakortokite have demonstrated a correlation between uranium content and stratigraphical height in the intrusion. The material collected in 1972 should confirm this observed trend. It will also be used in further geochemical studies of eudialyte.

The ore minerals of the intrusion (Svend Karup-Møller \& Laust Løkkegaard)

Ore minerals, mainly sulphides, were collected systematically throughout the intrusion. Laboratory examination of the material will be directed on three main topics: (1) the accessory ore minerals in the major rock types; (2) cuprostibite and accompanying minerals; (3) galena and sphalerite from hydrothermal veins including a study of the isotopic composition of the lead and sulphur of the galena.

\section{Globular structures and layering in lujavrite; late veins (Henning Sørensen)}

The globular structures previously documented in the lujavrite may be formed from liquids immiscible with the lujavrite magma. An experimental study of this problem has been started together with Dr. Lia Kogarko of Moscow and John Rose-Hansen. The late veins are studied mainly because of their rare element mineralisations.

Field mapping of part of the "lujavrite-breccia zone" (Steen Andersen \& Lars C. Larsen)

This zone, which forms a part of the largest area of arfvedsonite lujavrite in the whole intrusion, is situated around a hill $435 \mathrm{~m}$ south of Tunugdliarfik fjord. Special attention was given to the structural features in order to throw light on the mode of emplacement of the lujavrites. A systematic radiometric survey of the rocks of the area was carried out.

The area mapped is situated to the north-east of that worked by Aelita Demin 
(see GGU Reports of Activities for 1970 and 1971). It is hoped eventually to compile a new 1:10 000 map of that part of the instrusion situated to the south of Tunugdliarfik fjord.

S. A., J. B., S. K.-M., L. L., J. R.-H. \& H. S., Institut for Petrologi, University of Copenhagen, $\emptyset_{\text {stervoldgade 5-7, }}$ Copenhagen $K$.

\title{
PETROCHEMICAL WORK ON THE PRECAMBRIAN LAVAS, ERIKSFJORD FORMATION, SOUTH GREENLAND
}

\author{
Jørgen G. Larsen
}

The lavas of the Ilímaussaq Volcanic Member of the sandstone-volcanic Eriksfjord Formation (Stewart, 1964; Poulsen, 1964) can be subdivided into an upper Porphyry Division $(>600 \mathrm{~m}$ ) consisting mainly of trachytic rocks and a lower Basalt Division $(230-700 \mathrm{~m})$. To the south-west of the Ilímaussaq alkaline intrusion, the Basalt Division is markedly thinner (Stewart, 1964). During field work in 1970 samples of the volcanics were collected for petrochemical analysis. This report summarises the state of the subsequent laboratory work.

Forty-two major and trace element analyses have been made of the lavas. For norm calculation the $\mathrm{Fe}_{2} \mathrm{O}_{3} / \mathrm{FeO}$ ratios were corrected to 0.15 . There are no signs of fenitisation in the examined rocks except in those collected from close to the Ilimaussaq intrusion.

\section{The Basalt Division}

This comprises hypersthene-normative olivine basalts and hypersthene-normative hawaiites. These usually contain phenocrysts of plagioclase and pseudomorphed olivine. The plagioclase is generally slightly sericitised. When more extensively sericitised the lavas become nepheline-normative in accordance with Stewart's (1964) suggestions. Of the freshest lavas investigated, none are nepheline-normative. Although the hypersthene-normative content of some of these lavas is higher than in most basic rocks of the Gardar province, their mineralogy and trace element distribution are of alkaline affinity. The higher hypersthene norm may or may not be of primary origin - this will be discussed in a later publication. The highest $\mathrm{A}_{2} \mathrm{O}_{3}$ content recorded is $16.3 \%$ (plagioclase phenocrysts subtracted), being only found in the more primitive flows.

The chemical variation from olivine basalt to hawaiites can be explained by fractional crystallisation of the following normative composition (wt. $\%, 62 \%$ 